\title{
Indirect and direct Chapelle's methods for the determination of lime consumption in pozzolanic materials
}

\section{Métodos de ensaio indiretos e método Chapelle direto para determinação do consumo de cal pelos materiais pozolânicos}
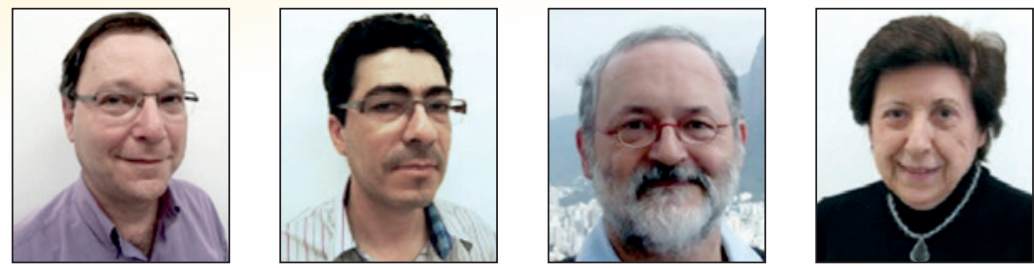

\author{
V. A. QUARCIONI a \\ quarciva@ipt.br \\ F. F. CHOTOLI a \\ fchotoli@ipt.br \\ A. C. V. COELHO b \\ acvcoelh@usp.br \\ M. A. CINCOTTO ${ }^{\circ}$ \\ cincotto@poli.usp.br
}

\begin{abstract}
In this work, comments are made about indirect methods and direct Chapelle's method applied to the determination of the reactivity of pozzolanic materials. The Chapelle's method is based on the lime-pozzolan reaction and quantifies the pozzolanic reactivity of any material intended to be applied by the cement industry. This lime consumption determination by the pozzolan through this reaction can be made with mass proportions - lime:pozzolan 1:1, as originally proposed by Chapelle or 2:1, as specified in Brazilian and French Standards. Comparative results with both proportions are presented for sugar cane bagasse ash, rice rusk ash, silica fume, fly ash, and metakaolin, commonly studied in our country. Statistical calculations showed that for some materials of similar characteristics to the researched RHA, FA e MK at issue, essays carried out with only $1 \mathrm{~g}$ of $\mathrm{CaO}$ may be underestimating the amounts of $\mathrm{CaO}$ consumed per gram of pozzolanic material that can be obtained. Comments were made about the Brazilian and French Standards based on this method and emphasized the expression of lime consumption per mass of the amorphous phase of these materials, as determined by $\mathrm{X}$ ray diffraction analysis with the Rietveld refinement method.
\end{abstract}

Keywords: pozzolanic reactivity, Chapelle's method, sugar cane bagasse ash, rice rusk ash, silica fume, fly ash, metakaolin

\section{Resumo}

Neste trabalho, são discutidos os métodos indiretos e método de Chapelle direto aplicados para a determinação da reatividade de materiais pozolânicos. O método Chapelle baseia-se na reação química cal-pozolana e quantifica a reatividade pozolânica de materiais destinados à aplicação pela indústria de cimento. A determinação do consumo de cal pela pozolana que ocorre por meio desta reação química pode ser feita empregando-se as proporções em massa cal: pozolana 1:1, como proposto originalmente por Chapelle, ou 2:1, conforme especificado nas normas técnicas brasileira e francesa. São apresentados os resultados comparativos com as duas proporcões cal-pozolana para cinza de bagaço de cana-de-açúcar, cinza de casca de arroz, sílica ativa, cinza volante e metacaulim, comumente estudados em nosso país. Os cálculos estatísticos indicaram para alguns materiais com características semelhantes aos da cinza de casca de arroz (CCA), cinza volante (CV) e metacaulim (MC), pesquisados em questão, que os ensaios realizados com apenas $1 \mathrm{~g}$ de $\mathrm{CaO}$ podem estar subestimando os valores obtidos de CaO consumidos por grama de material pozolânico. As normas brasileira e francesa foram discutidas com base nos resultados de ensaios Chapelle e enfatizou-se a quantificação do consumo de cal, em massa, pela fase amorfa destes materiais, que pode ser determinada pela análise de difração de raios-X por meio do método de refinamento de Rietveld.

Palavras-chave: reatividade pozolânica, método Chapelle, cinza de bagaço de cana-de-açúcar, cinza de casca de arroz, sílica ativa, cinza volante, metacaulim.

Instituto de Pesquisas Tecnológicas do Estado de São Paulo (IPT) - Laboratório de Materiais de Construção Civil, São Paulo, Brazil;

Escola Politécnica da Universidade de São Paulo - Departamento de Engenharia Metalúrgica e de Materiais. São Paulo, Brazil;

Escola Politécnica da Universidade de São Paulo - Departamento de Engenharia de Construção Civil, São Paulo, Brazil. 


\section{Introduction}

The chemical effect resulting from the application of pozzolanic materials, as Portland cement clinker substitution, modifies the intrinsic characteristics of the paste due to a reaction with calcium hydroxide, which is called pozzolanic activity. Calcium hydroxide - portlandite - is released during the hydration of calcium silicates of the clinker and reacts with the pozzolan, forming hydraulic compounds, the most important of which being calcium silicate hydrate $-\mathrm{C}-\mathrm{S}-\mathrm{H}-$ due to the contribution of its mechanical properties to the hydrated paste. Not less important is the refinement of the porous system resulting from the precipitation of hydrated products and the physical effect from the pozzolan fine fraction [1]. The pozzolanic material does not react immediately with Portland cement under ambient temperature and pressure. As found in literature, the reaction can start anytime between one and seven days, depending on the reactivity of the pozzolanic material. Although such reaction may not have begun, the pozzolan has a beneficia effect by decreasing the released by hydration, which is particularly important for the concrete mass. Mitigation of the alkali-aggregate reaction and reduction of the concrete's susceptibility to leaching are other beneficial effects which occur at later ages [1, 2].

Pozzolans are composed by inert crystalline phases and a reactive vitreous phase. The pozzolanic reaction is the interaction of the solubilized elements of the vitreous phase, in a strong alkaline medium, $\mathrm{pH} 13.5$, with the calcium ion present in the solution in contact with the cement [3]. Therefore, these materials are characterized by the degree of pozzolanic reaction, i.e., by its calcium consumption, which depends on: the Portland cement composition, with or without calcareous filler; the content and composition of the vitreous phase; cement and pozzolan specific surface area; the proportion cement:pozzolan.

Besides the quantification method of calcium consumption, the determination of the pozzolanic reactivity and its effect on the Portland cement hydration has been improved by the development of new methods of X-ray diffractometry applied to the qualitative determination in "real time", also called in situ, which allows the identification of the hydrated products formed during the first twenty hours, period in which the effects of additions and admixtures is studied, as well as their rheological properties. The analysis by the Rietveld refinement method quantifies the crystalline and vitreous phases, and the real consumption by the vitreous phase can be calculated; this determination applied over time allows the monitoring of the consumption of the vitreous phase and its effect on mortar or concrete properties $[4,5,6]$.

Other methods are applied to determine the pozzolanic interaction in hardened state systems, pozzolan-hydrated lime or pozzolanPortland cement. The portlandite consumption and the chemically combined water content are determined by thermogravimetry, following the reaction development $[7,8,9]$. The physical effect is commonly analyzed by the evolution of mechanical properties and porosity decrease.

Literature proposes a few methods for fly ash, which provide an indirect determination of pozzolanic reactivity. However, to explain the hydrated cement composition and the microstructure resulting from the interaction with the calcium from the cement and the elements of the pozzolan vitreous phase, the best way is the direct determination of the interaction degree of pozzolan-calcium oxide or calcium hydroxide. In fact, the direct determination conceived by Chapelle is at present a Standard Method in France for metakaolin [10], and in Brazil for pozzolanic materials in general [11]. In this work some comments are made about indirect methods published and the results of Chapelle's method applied to silica fume, fly ash, sugar cane bagasse and rice husk ashes, comparing the effect with the mass proportion lime: pozzolan $1: 1$, as originally proposed and 2:1 as specified in Brazilian and French Standards.

\section{Comments about methods to determine pozzolanic reactivity}

\subsection{Indirect methods to determine fly ash pozzolanic reactivity}

The most common criteria to determine pozzolanic activity is its strength activity index according to the ASTM C311 Standard [12] by applying the compressive strength test on a mix of cement-pozzolanic material. This test is indirect and does not give any information about the pozzolanic material itself, since the result depends on the chemical and physical characteristics of the cement.

Since the C-S-H is the reaction product with lime, which improves the mechanical properties, a high content of silica is the most important parameter of the vitreous phase. Raask \& Bhaskar [13] proposed evaluating the fly ash quality by measuring the electrical conductivity of the dissolved silica content in hydrofluoric acid $(0.1$ $\mathrm{M}$ at $300^{\circ} \mathrm{C}$, for 10 minutes) and the result inferred from a calibration curve plotted with silica fume. The authors admitted that in that concentration only the silica from the vitreous phase is solubilized. The most serious drawback to this method is that the authors did not prove that all silica present in the glass phase only was dissolved. Further, Majumdar \& Larner also questioned the applicability of this method for fly ash [14].

Considering that lime consumption is an indicative of pozzolanic reactivity, Luxán et al. [15] proposed measuring the conductivity of a suspension of an opaline rock in saturated calcium hydroxide, stirring at $40^{\circ} \mathrm{C}$. The conductivity decreased during the first 2 minutes then it stabilized. In the light of this result, this method was applied to a set of 100 natural materials, and a reactivity classification was proposed. The authors mentioned that during this period, the adsorption phenomenon is predominant, but did not seek to prove whether there was, in fact, early pozzolanic activity by chemical reaction. The method is therefore, questionable. However, Payá et al. [16] applied this method with modifications, on different fly ashes and concluded that the results were affected by: the soluble salts, the fly ash: lime suspension ratio, and the method does not apply to high-calcium fly ash.

Tashiro et al. [17] proposed to measure the resistivity of pastes of different materials with calcium hydroxide, steam cured at $70^{\circ} \mathrm{C}$ for 72 hours, determining the progress of the consumption of portlandite by XRD. No relationship was identified between the consumption of calcium hydroxide and the resistivity measurements.

Katyal et al. [18] were concerned only with the determination of the amount of active silica in fly ash, by comparing two treatments: a) initial heating in diluted hydrochloric acid until dry up, and the solid residue is digested in a digestion pump with potassium hexafluorosilicate; in the solution obtained, the hydrofluoric acid released by hydrolysis was titrated with sodium hydroxide. b) Digestion of an initial sample with diluted hydrochloric acid and then with a potassium 
hydroxide $25 \%$ solution and quantification of the solubilized silica. The issue that arises is that since the content of the glass phase has not been provided it does not show- whether or not the dissolution was complete and from what phase the dissolved silica came from. The purpose of these methods was the speed which the pozzolanic activity could be determined, but in practice it did not happen. Surface phenomena interfere with these results, especially those relating to the high specific surface area of fly ash. In addition, the beginning of the specific reactivity for each pozzolan, it is highly important to determine the age at which the lime consumption is more significant, and the extension of the reaction contributing to the mechanical properties of cementitious materials.

Concerning the hardened state of pastes or mortars, the extension of the interaction was determined by quantifying the calcium hydroxide consumption by thermogravimetry $[7,8,9]$, or by determining the amount of unreacted fly ash, both methods were applied after different periods of cure. To quantify the unreacted fly ash, the hydrated products were washed with selective reagents. Different reagents were studied - picric acid-methanol, salicylic acid-methanol, hydrochloric acid-sodium carbonate [2, 19, 20, 21] They all affect the results a little with some solubility of the fly ash, or the incomplete dissolution of hydrated products, which means that some corrections have to be made.

Direct determination of calcium consumption by Chapelle's test Chapelle's method modified by Raverdy et al. [22], is an accelerated method for the direct determination of the pozzolan lime consumption. A suspension of pozzolan/lime $(1 \mathrm{~g} / 1 \mathrm{~g})$ and a blank of lime are kept reacting at $90^{\circ} \mathrm{C}$ for 16 hours; the lime consumed is calculated by the difference between the added and the remaining lime. This method was applied on industrial Portland pozzolanic cements and also on laboratory prepared with three Portland cements of different contents of $\mathrm{C}_{3} \mathrm{~A}$ and seven pozzolans, whose substitution levels were $10 \%, 20 \%$ and $35 \%$ at the same Blaine fineness, totalizing 63 samples. The authors evaluated the contribution of pozzolanic reactivity by comparing any increase in the compressive strength of the cements with pozzolans, after 28 days, with the corresponding pozzolan cements without addition. This study had the merit of indicating a minimum consumption as a reference data obtained from pozzolanic cements. Strength resistance at 180 days was plotted against the content of the glass phase [23] indicating only the gain for pozzolans for which lime consumption was greater than $330 \mathrm{mg}$ per gram of glass phase. In France, the Chapelle's method was specified to select metakaolin for addition in concrete. The conformity criteria [10] are: (a) the content of $\mathrm{SiO}_{2}+\mathrm{Al}_{2} \mathrm{O}_{3}>90 \%$, calcined between $600^{\circ} \mathrm{C}$ and $850^{\circ} \mathrm{C}$; this result means that metakaolin has to be obtained from high quality kaolin; (b) the loss on ignition has to be $<4.0 \%$; compared to the theoretical ignition loss of pure kaolin, of $13.76 \%$. Thus, we can conclude that the kaolin must have a transformation degree of at least $70 \%$; (c) the specified calcium hydroxide consumption has to be $700 \mathrm{mg} / \mathrm{g}$ of metakaolin $\left[700 \mathrm{mg}\right.$ of $\mathrm{Ca}(\mathrm{OH})_{2}$ is equal to 530 $\mathrm{mg}$ of $\mathrm{CaO}$ ]. In this standard method, the reaction is one gram of metakaolin and two grams of lime.

Chapelle's method was standardized too by ABNT - Associação Brasileira de Normas Técnicas (NBR 15895:2010), being applicable to natural and artificial pozzolans - calcined clay minerals, fly ash, silica fume and metakaolin but not to siderurgical slags [11]. In fact, it is also not applicable to metallurgical slags, as granulated blast furnace slag.

\section{Experimental}

Chapelle's method is commonly applied by the IPT- Construction Materials Laboratory for pozzolanic reactivity determination of different materials. Raverdy's et al. procedure underwent some adjustments to obtain a good reproduction of results. The results obtained with one gram of lime were carried out before the Brazilian Standard publication.

Test: All materials have their fineness specified, that is, a maximum residue of $12 \%$ of $45 \mu \mathrm{m}$, or around $800 \mathrm{~m}^{2} / \mathrm{kg}$. One gram of pozzolan is mixed with one gram of calcium oxide, added to $250 \mathrm{~mL}$ water in a $500 \mathrm{~mL}$ plastic Erlenmeyer and sealed. Calcium oxide is obtained from the calcination of a calcium carbonate pure reagent for analysis at $1000^{\circ} \mathrm{C}$ for 1 hour. After, the material is mixed quickly and manually and calcined for an additional half hour. The pozzolanic-lime mix and a blank are kept at $90 \pm 5^{\circ} \mathrm{C}$ in a closed Dubnoff shaking water bath for $16 \pm 2$ hours (Fig. 1A and 1B), with some Teflon rods and stainless steel little balls. After cooling, 250 $\mathrm{mL}$ of a saccharose solution $(240 \mathrm{~g} / \mathrm{L})$ is added (Fig. 1C), Erlenmeyer is closed and the solution shaken for fifteen minutes (Fig. 1D); it is then filtered (Fig. 1E) through a pleated filter paper with an aliquot of $50 \mathrm{~mL}$, the alkalinity is determined with hydrochloric acid $0.1 \mathrm{M}$ (Fig. 1I). During the filtration (Fig. $1 \mathrm{~F}$ and $1 \mathrm{G}$ ) and pipetting (Fig. $1 \mathrm{H}$ ) phases it is important to carry them out as fast as possible to avoid carbon dioxide absorption. The result is expressed in reacted milligrams of lime $(\mathrm{CaO})$ reacted or fixed per gram of pozzolan.

Figure 1-A illustrates the Nova Ética, type 304E Thermostatic Bath, with a digital microprocessed controller, at a $0.1^{\circ} \mathrm{C}$ resolution and a sensor Pt-100. The bath reservoir has an available capacity of $12 \mathrm{~L}$ of water, which is enough to maintaining the level of the Erlenmeyer solution covered, kept constant. The evaluation of its thermal profile showed that the $4^{\circ} \mathrm{C}$ temperature gradient does not interfere with the test results [24].

Calculation considering $2 \mathrm{~g}$ of $\mathrm{CaO}$ and $1 \mathrm{~g}$ of pozzolan:

$m g$ CaO per gram of material $=\frac{28 x\left(v_{3} x m_{3}-v_{2}\right) x F_{c} \times 2 \times 2}{m_{4} x m_{3} x m_{2}}$ (1)

being:

$\mathrm{m}_{2}=$ grams of pozzolanic material;

$\mathrm{m}_{3}=$ grams of $\mathrm{CaO}$ mixed with pozzolanic material;

$\mathrm{m}_{4}=$ grams of $\mathrm{CaO}$ in the blank test;

$\mathrm{v}_{2}=$ milliliters of $\mathrm{HCl} 0.1 \mathrm{M}$ consumed by the sample solution;

$\mathrm{v}_{3}=$ milliliters of $\mathrm{HCl} 0.1 \mathrm{M}$ consumed by the blank solution;

$\mathrm{F}_{\mathrm{c}}=$ correction factor of $\mathrm{HCl} 0.1 \mathrm{M}$ standard solution.

\section{Results and discussion - calcium consumption of different pozzolans}

Regarding to the reference metakaolin, the medium, maximum, minimum and standard deviation results are presented on Table 1. We can see that although consumption increases, the result with $2 \mathrm{~g}$ is not the double of the result with $1 \mathrm{~g}$. The Table also presents the calcium oxide results determined and calculated as calcium hydroxide $(\mathrm{CaO} \times 1.32)$. Tables 2 and 3 illustrate the results of the 


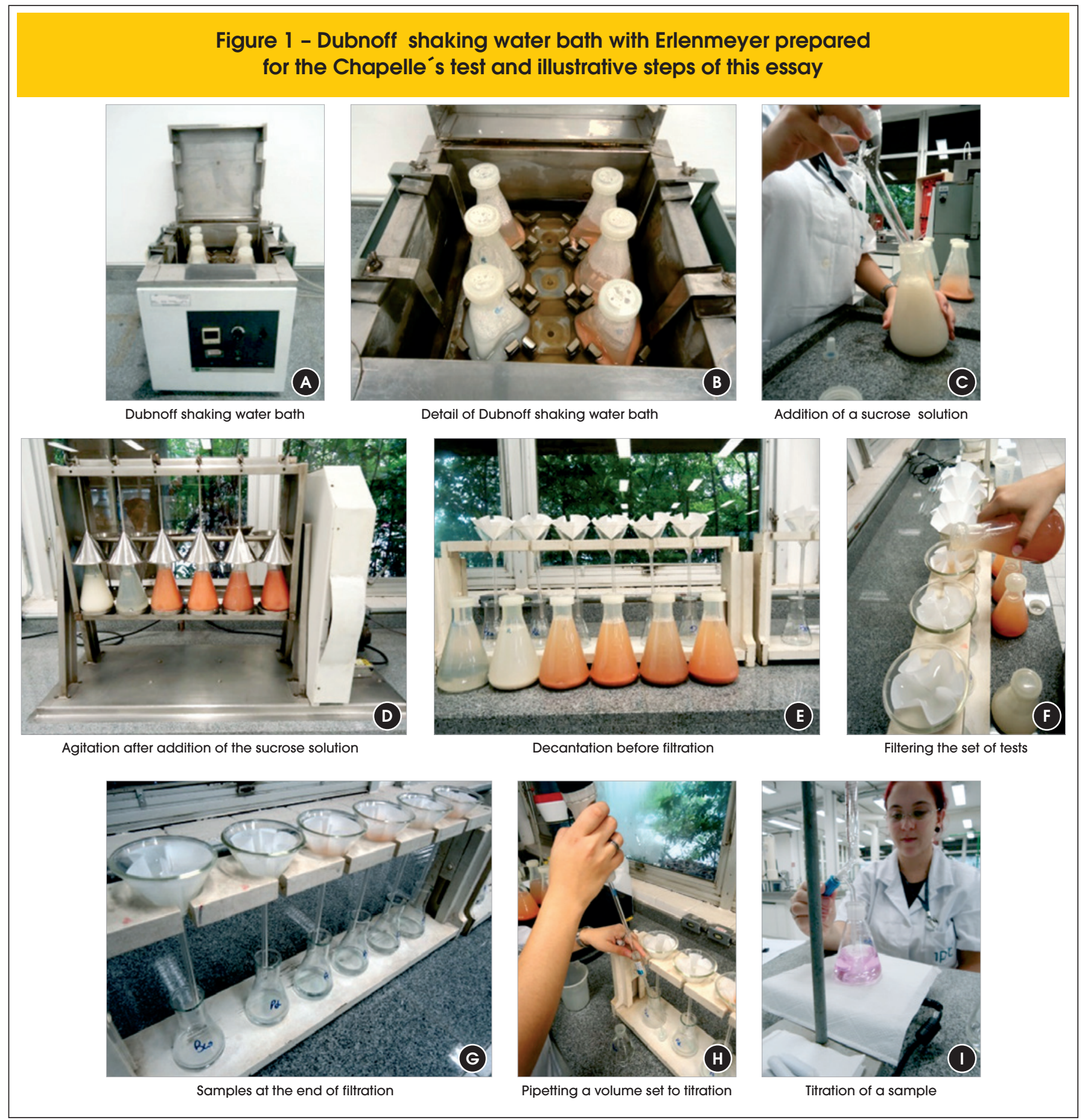

pozzolanic materials analyzed in the IPT's Laboratory in the last three years, tests being carried out with one gram and two grams of calcium oxide, respectively.

\section{Results and discussion - calcium consumption of different pozzolans}

Regarding the reference metakaolin, the mean, maximum, minimum and standard deviation results are presented on Table 1. We can see that the $\mathrm{CaO}$ consumption increases. Table 1 also presents calcium oxide results calculated as calcium hydroxide $(\mathrm{CaO} \times 1.32)$. Table 2 illustrates the calcium consumption of the pozzolanic materials that has been analyzed in IPT's Laboratory in the last three years, tests being carried out with one gram and two grams of calcium oxide. Analysis of variance (ANOVA) was carried out between $1 \mathrm{~g}$ and $2 \mathrm{~g}$ results in order to observe if one gram of calcium oxide is sufficient to consume all the existing vitreous phase in pozzolanic material. Figure 2 presents graphically the dispersion of the results. 
Table 1 - Calcium consumption of metakaolin as the reference material

\begin{tabular}{|c|c|c|c|c|}
\hline \multirow[b]{2}{*}{ Calcium consumption } & \multicolumn{2}{|c|}{ Test with $1 \mathrm{~g}$ of CaO (188 tests) } & \multicolumn{2}{|c|}{ Test with $2 \mathrm{~g}$ of CaO (56 tests) } \\
\hline & $\begin{array}{c}\text { CaO } \\
\mathrm{mg} / \mathrm{g} \text { sample }\end{array}$ & $\begin{array}{c}\mathrm{Ca}(\mathrm{OH})_{2} \\
\mathrm{mg} / \mathrm{g} \text { sample }\end{array}$ & $\begin{array}{c}\text { CaO } \\
\mathrm{mg} / \mathrm{g} \text { sample }\end{array}$ & $\begin{array}{c}\mathrm{Ca}(\mathrm{OH})_{2} \\
\mathrm{mg} / \mathrm{g} \text { sample }\end{array}$ \\
\hline Medium & 857 & 1131 & 1068 & 1410 \\
\hline Maximum & 876 & 1156 & 1134 & 1497 \\
\hline Minimum & 833 & 1100 & 973 & 1284 \\
\hline Standard deviation & 11 & - & 48 & - \\
\hline
\end{tabular}

A wide result variation was observed in three materials: sugar cane bagasse ash (SCBA), rice husk ash (RHA) and silica fume (SF). SCBA and RHA are generally collected at the production site and calcined under temperature conditions and residence time specific to each research laboratory. Consequently, the composition of the ash and content of vitreous phase may vary. The region from where they come from also influences their composition due to the type of fertilizer employed. This can explain the significant calcium consumption difference for these two materials.

$\mathrm{SF}$, on the contrary, comes from industrial processes under controlled conditions and should have homogeneous characteristics which restricts the variation of calcium consumption. At the moment, we have no explanation for the wide degree of variation observed.

Fly ash (FA) and metakaolin (MK) also come from industrial processes under controlled conditions. In the case of these two materials, the variation of the results was quite small as expected.

An analysis of variance (ANOVA) carried out for the $1 \mathrm{~g}$ and $2 \mathrm{~g} \mathrm{CaO}$ results made it possible to confirm that the results of consumed $\mathrm{CaO}$ are statistically equal, whether starting from $1 \mathrm{~g}$ or $2 \mathrm{~g}$ of $\mathrm{CaO}$, for sugar cane bagasse ash and for fly ash. It can be said that for these two types of materials, $1 \mathrm{~g} \mathrm{CaO}$ is sufficient to consume practically the whole vitreous phase contained in one gram of pozzolanic material, and that an increase in the amount of $\mathrm{CaO}$ does not give rise to an increase in consumption.
In the other tested materials (RHA, FA and MK), the increase in the amount of $\mathrm{CaO}$ initially added (from $1 \mathrm{~g}$ to $2 \mathrm{~g}$ ) gives rise to a statistically significant increase in $\mathrm{CaO}$ consumption. These materials should have vitreous phases whose nature and/or amount are such that they do not completely react when only $1 \mathrm{~g}$ of $\mathrm{CaO}$ is added, and require a higher lime concentration. This finding, in addition to the metakaolin results presented on Table 1, suggest that for some materials of similar characteristics to the researched $\mathrm{RHA}, \mathrm{FA}$ e MK at issue, essays carried out with only $1 \mathrm{~g}$ of $\mathrm{CaO}$ may be underestimating the amounts of $\mathrm{CaO}$ consumed per gram of pozzolanic material that can be obtained. For this very reason, the French and Brazilian standards were objective by adopting the use of $2 \mathrm{~g}$ of $\mathrm{CaO}$.

\section{Conclusions}

The number of tests made with metakaolin illustrates the good reproducibility of the method for each lime-pozzolan proportion.

The difficulty found in applying Chapelle's method as disclosed by Raverdy et al. was the glassy phase determination, which has now been solved with the introduction of the Rietveld refinement method of the XRD analysis interpretation. All these results of calcium consumption refer to the pozzolanic material as received; real consumption cannot be given because the vitreous phase was not determined.

\section{Table 2 - Calcium consumption ( $\mathrm{g}$ of $\mathrm{CaO} / \mathrm{g}$ of pozzolanic material) of different pozzolanic materials. Tests were carried out with $1 \mathrm{~g}$ or $2 \mathrm{~g}$ of CaO. SCBA = sugar cane bagasse ash; RHA = rice husk ash; FA = fly ash; MK = metakaolin; SF = silica fume}

\begin{tabular}{|c|c|c|c|c|c|c|c|c|c|c|}
\hline & \multicolumn{2}{|c|}{ SCBA } & \multicolumn{2}{|c|}{ RHA } & \multicolumn{2}{|c|}{ FA } & \multicolumn{2}{|c|}{ MK } & \multicolumn{2}{|c|}{ SF } \\
\hline & $\lg$ & $2 g$ & $1 g$ & $2 g$ & $\lg$ & $2 g$ & 19 & $2 g$ & $\lg$ & $2 g$ \\
\hline Mean value & 279 & 298 & 622 & 864 & 269 & 403 & 656 & 842 & 755 & 1089 \\
\hline Minimum value & 146 & 143 & 255 & 559 & 174 & 286 & 579 & 752 & 394 & 967 \\
\hline Maximum value & 468 & 568 & 867 & 1080 & 378 & 489 & 804 & 1015 & 858 & 1153 \\
\hline Standard deviation & 106 & 145 & 141 & 179 & 97 & 91 & 50 & 101 & 117 & 71 \\
\hline Number of materials & 7 & 13 & 16 & 6 & 4 & 4 & 17 & 8 & 16 & 5 \\
\hline $\begin{array}{l}\text { ANOVA analysis - with } 95 \% \\
\text { confidence, } 1 \mathrm{~g} \text { and } 2 \mathrm{~g} \text { results are: }\end{array}$ & & & & & & & & & & \\
\hline
\end{tabular}


However, these results allow us to emphasize that the conclusions drawn about the chemical effect of the properties of Portland cements where the clinker has been replaced by pozzolan have to take in account the real content of the vitreous phase and the effective reactivity.

Chapelle's method quantifies the calcium consumption related to the amorphous or vitreous phase of pozzolanic materials. The Rietveld refinement method gives the percentage of the amorphous and vitreous phase. These available methods allow correlating the effective calcium consumption with the effect of mechanical properties of the cements with clinker replacement by pozzolanic materials.

\section{Acknowledgements}

The authors are very thankful to Instituto de Pesquisas Tecnológicas (IPT) for its permission to publish these results and the financial support for this study.

\section{References}

[01] MASSAZZA, F. Pozzolans and pozzolanic cements. In: Lea's chemistry of cement and concrete. Edited by Peter C. Hewlett. Fourth Edition. 1998.

[02] UCHIKAWA, H. Effect of blending components on hydration and structure formation. In: 8th INTERNATIONAL CONGRESS ON THE CHEMISTRY OF CEMENT (ICCC). Special Reports - Vol. 1, p. 249 - 280. Rio de Janeiro, 1986.

[03] UCHIKAWA, H., USHIDA, S., HANEHARA, S Effect of character of glass phase in blending components on their reactivity in calcium hydroxide mixture. 8th INTERNATIONAL CONGRESS ON THE CHEMISTRY OF CEMENT. VoI. IV, Rio de Janeiro - Brazil, 1980, 245- 250.

[04] HESSE, C., GOETZ-NEUNHOEFFER, F., NEUBAUER, J., BRAEU, M., GAEBERLEIN, P. Quantitative in-situ x-ray diffraction analysis of early hydration of portland cement at defined temperatures. JCPDS-International Centre for Diffraction Data 2009 ISSN 1097-0002.

[05] WARD, C. R.; FRENCH, D. Determination of glass content and estimation of glass composition in fly ash using quantitative X-ray diffractometry. Fuel, Volume 85, Issue 16, p. 2268 - 2277, November 2006.

[06] GOBBO, L. A.; SANT'AGOSTINO, L. M.; D'AGOSTINO, L. Z. XRD-Rietveld quantitative analysis of glass-containing byproducts used in the Brazilian cement industry, 12th International Congress on the Chemistry of Cements. Montreal, Canada, 2007.

[07] VEDALAKSHMI, R.; RAJ, A. S.; SRINIVASAN, S.; BABU, K. G. Quantification of hydrated cement products of blended cements in low and medium strength concrete using TG and DTA technique. Thermochimica Acta, Vol. 407, Issues 1 - 2, p. 49 - 60, December 2003.

[08] ROSZCZYNIALSKI, W. Determination of pozzolanic activity of materials by thermal analysis. Journal of Thermal Analysis and Calorimetry, Vol. 70, Number 2, p. 387 - 392, September 2002.

[09] BAERT, G., HOSTE, S., De SHUTTER, G., De BELLIE, N. Reactivity of fly ash in cement paste studied by means

Figure 2 - Calcium consumption ( $\mathrm{g}$ of $\mathrm{CaO} / \mathrm{g}$ of vitreous of materials) of different pozzolanic materials. Tests were carried out with $1 \mathrm{~g}$ (solid lines) or $2 \mathrm{~g}$ (hollow lines) of CaO. Vertical lines represent the scattering of the results; mean values are shown as horizontal dashes. SCBA = sugar cane bagasse ash; RHA = rice husk ash; FA = fly ash; MK = metakaolin; SF = silica fume

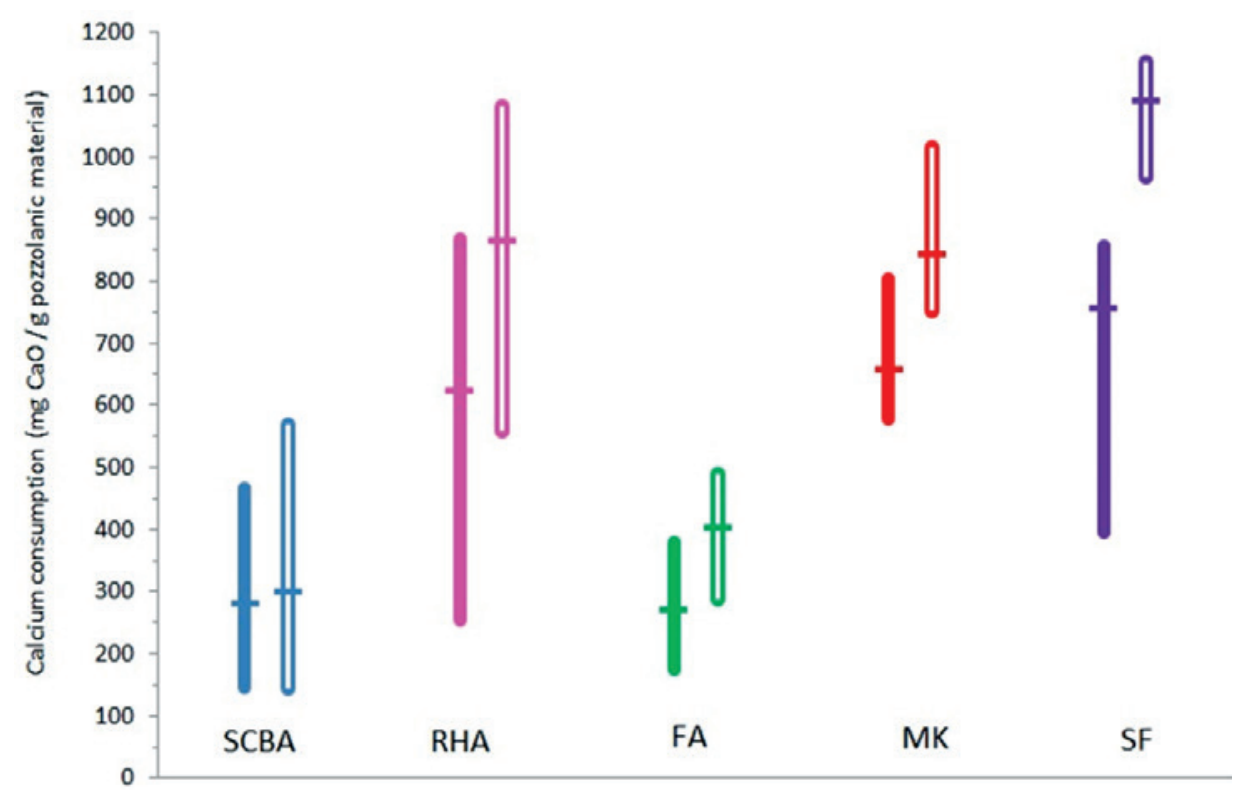


of thermogravimetry and isothermal calorimetry. Journal of Thermal Analysis and Calorimetry, 94, Issue 2 (2008) 485-492.

[10] AFNOR - Association Française de Normalisation - Standard NF P 18-513/2010 - "Pozzolanic addition for concrete - Metakaolin - Definitions, Specifications and Conformity Criteria,19 $p$

[11] ABNT- Associação Brasileira de Normas Técnicas NBR 15.895/10 "Materiais pozolânicos - Determinação do teor de hidróxido de cálcio fixado - Método Chapelle modificado"

[12] American Society for Testing and Materials - ASTM C 311 Standard methods for sampling and testing fly ash in natural pozzolans for use as a mineral admixture in Portland cement concrete.

[13] RAASK, E., BHASKAR, M. C., Pozzolanic activity of pulverized ash, Cement and Concrete Research, 5(1975) 363-375.

[14] MAJUMDAR, A. J., LARNER, L. J., The measurement of pozzolanic activity (Note), Cement and Concrete Research, 7 (1977) 209-210.

[15] LUXÁN, M. P., MADRUGA, F., SAAVEDRA, J. Rapid evaluation of pozzolanic activity of natural products by conductivity measurements, Cement and Concrete Research, 19 (1989) 63-68.

[16] PAYÁ, J., BORRACHERO, M. V., MONZÓ, J., PERIS-MORA, E., AMAHJOUR, F., Enhanced conductivity measurement techniques for evaluation of fly ash pozzolanic activity, Cement and Concrete Research, 31(2001) 41-49.

[17] TASHIRO, C., IKEDA, K., INOUE, Y., Evaluation of pozzolanic activity by the electric resistance measurement method. Cement and Concrete Research, 24(1994) 1133-1139.

[18] KATYAL, N. K., SHARMA, J. M., DHAVAN, A.K., ALI, M. M., MOHAN, K., Development of a rapid method for the estimation of reactive silica in fly ash, Cement and Concrete Research, 38 (2008) 104-106.

[19] OHSAWA, R., ASAGA, K, GOTO, S., Daimon, M. Quantitative determination of fly ash in hydrated fly ash-CaSO4-Ca(OH)2. Cement and Concrete Research, 15 (1985) 357-366.

[20] SHIQUN LI, DELLA M. ROY, AMITHABA KUMAR, Quantitative determination of pozzolans in hydrated systems of cement or $\mathrm{Ca}(\mathrm{OH}) 2$ with fly ash or silica fume, Cement and Concrete Research, 13(1985) 1079-1086.

[21] BEN HAHA, M., E Weerdt, K., LOTHENBACH Quantification of the degree of reaction of fly ash. Cement and Concrete Research, 40 (2010)14620-11629.

[22] RAVERDY, M.; BRIVOT, F.; PAILLERE, A. M.; DRON, R. Appreciation of pozzolanic reactivity of minor components. 7th INTERNATIONAL CONGRESS ON THE CHEMISTRY OF CEMENT. Vol. 3, Paris, France, 1980.

[23] MILLET, J., HOMMEY, R., BRIVOT, F. Dosage de la phase vitreuse dans les matériaux pozzolaniques. Bulletin $n^{\circ}$. 92, 1977, 101-104.

[24] CHOTOLI, F. ,F., ALEIXO, D.M., COSTA, R.G., CASTANHO, M. A. P. Avaliação do perfil térmico de banho-maria com agitação tipo "Dubnoff" ENQUALAB-2007 - Congresso da Qualidade em Metrologia-Rede Metrológica do Estado de São Paulo - REMESP- SP, 2007. 